\title{
An Investigation into the Relationship between Agricultural Production and Formal Credit Supply in Nigeria
}

\author{
Aliyu A. Ammani \\ Agricultural Economics, Policy and Resource Management Programme, National Agricultural Extension and Research Liaison \\ Services, Ahmadu Bello University, Zaria, Nigeria
}

\begin{abstract}
Nigerian agriculture by nature is essentially traditional and subsistence. Limited access to credit facilities has been implicated as hinderance to the growth and productivity of the agricultural sector. Thus, the need arises for the provision of credit to the majority of Nigerian farmers. To increase farmers' access to credit from formal sources, the Federal Government of Nigeria established the Agricultural Credit Guarantee Scheme Fund (ACGSF) in 1977, with the purpose of increasing the level of bank credit to the agricultural sector through the provision of guarantee in respect of loans granted by any bank for agricultural purposes. This paper set out to investigate the relationship between agricultural production and formal credit supply in Nigeria. The methodology employed in the study involved the development and estimation of three simple regression models relating agricultural output with formal credit while holding other explanatory variables constant. Findings of the paper indicates that formal credit is positively and significantly related to the productivity of the crop, livestock and fishing sectors of Nigerian agriculture. Based on the findings it is recommended that government should continue to encourage the expansion of formal credit sources to reach as much farmers as possible.
\end{abstract}

Keywords Formal Credit, Agricultural Output, ACGSF, Nigeria

\section{Introduction}

Nigerian agriculture is essentially traditional and subsistence in nature. Given the requirement of finance in the agricultural sector, very few farmers will have capital of their own to invest in agriculture. Most farm families hardly have any savings to plough back into production, considering the pattern of their income and expenditure. Limited access to credit facilities has been implicated as hinderance to the growth and productivity of the agricultural sector (Ammani et al, 2010). Thus, the need arises for the provision of credit to the majority of Nigerian farmers.

The importance of credit to agricultural development cannot be overemphasised. Credit enables farmers to advantegoeusly use inputs and factors of production, by granting farmers more access to resources through the removal of financial constraints. The traditional argument for the provision of agricultural credit is that additional capital can be temporarily used to enhance the level of household's productive and physical capital (Eswaram and Kotwal, 1990). The provision of credit will reduce the costs of capital

* Corresponding author:

aaammani@yahoo.co.uk (Aliyu A. Ammani)

Published online at http://journal.sapub.org/ijaf

Copyright (C) 2012 Scientific \& Academic Publishing. All Rights Reserved intensive technology and assets relative to family labour. Thus, instead of growing low yielding local crops, for example, access to credit may allow an incresed use of improved seeds and fertilizers leading to higher crop output per unit of labour and land (Feder et al, 1985). This may in turn encourage the adoption of labour-saving technologies, such as animal traction in crop production (Zeller, 1999). Carter (1989) argued that credit could lead to efficient resource allocation, increase farmers' technical efficiency and, by implication, increase farmers' profitability. Qureshi et al (1996) observed that an increase in credit to agriculture will lead to increase food production and farmers' income because as the demand for credit increases, farmers output also increases, resulting in improvement in their well being.

Agricultural credit services are provided by both formal and informal institutions. The informal sector remains the leading provider of agricultural credit. Consequent of their poor resource endowment, most farmers are un-able to meet the stipulated criteria for formal credit especially that of pledging collaterals for loans, which is a basic requirement for credit transactions with formal financial institutions. As a result, poor farmers are left with no option other than to source credit from informal sources, which are regarded as exploitative because they mostly charge higher interest rates, much to the disadvantage of the farmers. In fact, according to the World Bank (1994) and (2000), the three most important 
sources of rural credit in Nigeria are all informal: (i) rotating savings and credit associations (RoSCAs) locally known as "adashi" or "esusu", (ii) family, and (iii) friends. Commercial banks came fourth, with only 11 percent of the sampled rural dwellers sourcing credit from them.

To increase farmers' access to credit from formal sources, the then Federal Military Government of Nigeria established the Agricultural Credit Guarantee Scheme Fund (ACGSF) under the Agricultural Credit Guarantee Scheme Fund Decree 1977. The purpose of the Fund is to increase the level of bank credit to the agricultural sector through the provision of guarantee in respect of loans granted by any bank for agricultural purposes. The Agricultural purposes in respect of which loans can be guaranteed by the fund are those connected with:- (a) establishment or management of plantation for the production of rubber, oil palm, cocoa, coffee, tea and similar crops; (b) The cultivation or production of cereal crops, tubers, fruits of all kinds, cotton, beans, groundnuts, sheanuts, benniseed, vegetables, pine-apples, bananas and plantains; (c) Animal husbandry, that is to say, poultry, piggery, cattle rearing and the like, fish farming and fish capture; (d) Processing in general where it is integrated with a least $50 \%$ of farm output e.g. cassava to gari, oil palm fruit to oil and kernel, groundnut to groundnut oil, etc. (e) Farm machinery and hire services (CBN, 1990).

As observed by Okon and Nkang (2009), the ACGSF is founded on the credit guarantee principle, designed to overcome the reluctance exhibited by financial institutions towards lending to the disadvantaged borrowers targeted by the scheme. Formal financial institutions are averse to lending to these groups of people because of stagnant agricultural markets, high production risk and perceived low profitability of farming, lack of collateral, and their poor financial recording systems (FAO, 2006). Credit guarantees are aimed at stimulating lending to credit-worthy borrowers with feasible projects, who however lack sufficient assets to offer as collaterals (Reichmuth, 1997). Guarantee schemes, leverage additional funds or "additionality" from the financial system because lenders make loans that otherwise would not have been made (Hollinger, 2004).

Have the ACGSF impacted on the availability of formal credit for agricultural production in Nigeria? The main purpose of this paper is to investigate the relationship between agricultural production and formal credit supply in Nigeria.

Specific objectives of the paper are to ascertain:

(i) The relationship between aggregate output of the crop sector and aggregate amount of formal credit to the crop sector.

(ii) The relationship between aggregate output of the livestock sector and aggregate amount of formal credit to the livestock sector.

(iii) The relationship between aggregate output of the fishing sector and aggregate amount of formal credit to the fishing sector.

The following hypotheses were formulated and tested in this study: (a) There is no significant relationship between aggregate output of the crop sector and aggregate amount of formal credit to the crop sector.

(b) There is no significant relationship between aggregate output of the livestock sector and aggregate amount of formal credit to the livestock sector.

(c) There is no significant relationship between aggregate output of the fishing sector and aggregate amount of formal credit to the fishing sector.

\section{Methodology}

(a). Conceptual Framework.

Our primary interest is to study the effect of credit on agricultural production. When capital is split up, it takes two forms: equity capital and non-equity capital. Credit is the non-equity capital. The conceptual framework for this study is based on the following arguments: (i) that increase in the productivity of each subsector of the Nigerian agricultural sector, will result from increase in the quantity of credit available to each subsector; (ii) that any change in the quantity of available credit to each agricultural subsector, will indicate a change in the output of the agricultural subsector. (b). Analytical Framework.

The analytical framework for this study is based on the following assumptions: (a) Credit is the only variable form of capital available for agricultural production, all other factors of production remains constant. (b) ACGSF guaranteed loans are the only source of agricultural credit available to Nigerian farmers. Thus, ACGSF guaranteed credits are taken as proxies to formal agricultural credit in Nigeria. (c) There is no time lag between credit acquisition and credit utilization for agricultural production. (d) Credit acquisition and utilization relate to agricultural production of the same year. (e) There are no changes in the price level. (f) There are no changes in technology. (g) Output of each subsector of the Nigerian agriculture equals the GDP of that subsector. Thus, GDP for each subsector of the Nigerian agricultural sector was taken as proxy for the output of that sector. (i) There exist a linear relationship between agricultural output and credit.

Based on the conceptual framework above, and the foregoing assumptions, the models for this study were developed as follows:

Consider a typical farm with a production function

$$
\mathrm{Y}=\mathrm{f}\left(\mathrm{X}_{1} \ldots \mathrm{X}_{\mathrm{m}} ; \mathrm{Z}_{1} \ldots \mathrm{Z}_{\mathrm{n}}\right)
$$

Where $\mathrm{Y}$ is output, $\mathrm{x}$ represent variable inputs and $\mathrm{z}$ represent fixed and other shifter variables of the function. Ignoring the fixed costs, the production function becomes

$$
\mathrm{Y}=\mathrm{f}\left(\mathrm{X}_{1} \ldots \mathrm{X}_{\mathrm{m}}\right)
$$

The Production function (2) can be re-written as follows:

$$
\mathrm{Y}=\mathrm{f}(\mathrm{C}, \mathrm{L}, \mathrm{M}, \mathrm{T})
$$

Where: C, L, M and T represents capital, labour, management practices and technical progress respectively. Taking credit as the variable of interest for this study, we dropped labour, management practices and technical pro- 
gress. The equation then becomes

$$
\mathrm{Y}=\mathrm{f}(\mathrm{C})
$$

Assuming capital to consist essentially of savings and credit, i.e $\mathrm{C}=\mathrm{S}+\mathrm{Cr}$, we can re-write the equation as follows

$$
\mathrm{Y}=\mathrm{f}(\mathrm{S}+\mathrm{Cr})
$$

Assuming the absence of savings, as is the case with most farmers, credit is taken as the only form of capital available for agricultural production; the function can then be re-written as follows

$$
\mathrm{Y}=\mathrm{f}(\mathrm{Cr})
$$

Based on the function (equation 6) developed above, an empirical aggregate model is developed to capture the effects of credit on the aggregate production of the various sub-sectors of Agriculture in Nigeria, leaving out variables of less interest to this study, as follows

$$
\mathrm{Ys}_{\mathrm{t}}=\beta_{0}+\beta_{1} \mathrm{Cr}_{\mathrm{st}}+\mu_{\mathrm{t}}
$$

Where $\mathrm{Ys}_{\mathrm{t}}$ is total output of the respective sub-sector of the Nigerian agriculture in year $\mathrm{t}$ (measured in MT) and $\mathrm{Cr}_{\mathrm{st}}$ is total amount of formal credit allocated to the sub-sector in year $t$ (measured in millions of Naira).

From a practical point of view, the GDP, expressed in millions of Naira, is considered a more plausible and easier measurement of sectoral output. Thus, we substitute $\mathrm{Ys}_{\mathrm{t}}$ with $\mathrm{GDPs}_{\mathrm{t}}$. The model then becomes

$$
\mathrm{GDPs}_{\mathrm{t}}=\beta_{0}+\beta_{1} \mathrm{Cr}_{\mathrm{st}}+\mu_{\mathrm{t}}
$$

Where GDPs $s_{t}$ represent the output of each subsector of Nigerian Agriculture, measured in millions of Naira.

Replicating equation (8) the following three models are developed for this study:

$$
\text { (i). } \mathrm{GDPC}_{\mathrm{t}}=\beta_{0}+\beta_{1} \mathrm{CrC}_{\mathrm{t}}+\mu_{\mathrm{t}}
$$

Where $\mathrm{GDPC}_{t}$ is the aggregate output of the crop sector of the Nigerian agriculture in year $t$ (in millions of Naira) and $\mathrm{CrC}_{\mathrm{t}}$ is total amount of formal credit made available to the crop sector in year $\mathrm{t}$ (in millions of Naira).

$$
\text { (ii). } \mathrm{GDPL}_{\mathrm{t}}=\beta_{0}+\beta_{1} \mathrm{CrL}_{\mathrm{t}}+\mu_{\mathrm{t}}
$$

Where $\mathrm{GDPL}_{t}$ is the aggregate output of the livestock sector of the Nigerian agriculture in year $t$ (in millions of Naira) and $\mathrm{CrL}_{\mathrm{t}}$ is total amount of formal credit made available to the livestock sector in year $\mathrm{t}$ (in millions of Naira).

$$
\text { (iii). } \mathrm{GDPF}_{\mathrm{t}}=\beta_{0}+\beta_{1} \mathrm{CrF}_{\mathrm{t}}+\mu_{\mathrm{t}}
$$

Where $\mathrm{GDPF}_{\mathrm{t}}$ is the aggregate output of the fishing sector of the Nigerian agriculture in year $t$ (in millions of Naira) and $\mathrm{CrF}_{\mathrm{t}}$ is total amount of formal credit made available to the fishing sector in year $t$ (in millions of Naira).

(c). Estimation of the models

(i)The Crop Sector Output-Formal Credit Model

As noted in various literature, empirical analysis of time series data pose several challenges as empirical work, including causality tests of Granger and Sims based on time series data assumed that the underlying time series is stationary (see Seddighi et al (2000); Enders (1995); Patterson (2000). Mercifully, as Gujarati (2003) noted, by simply establishing stationarity of the residuals from regression equation, if they are stationary, the traditional regression methodology is applicable to data involving non stationary time series.

Cointegration was tested on the data collected for this study using the Cointegrating Regression Durbin-Watson (CRDW) Test method as expounded by Gujarati (2003).

Our regression model:

$$
\mathrm{GDPC}_{\mathrm{t}}=\beta_{0}+\beta_{1} \mathrm{CrC}_{\mathrm{t}}+\mu_{\mathrm{t}}
$$

was estimated and the residuals obtained.

The computed CRDW $d$ (1.533) obtained from the cointegrating regression (9) is greater than the critical value of 0.386 at the $5 \%$ level, thus it was concluded that the regression residuals are stationary. Furthermore, the estimated DW $d$ value of 1.533 is greater than the critical $\mathrm{DW} \mathrm{d}_{\mathrm{U}}$ value of 1.483 indicating that there is no evidence of positive first order serial correlation. Thus, our OLS estimators for equation (9) are efficient and the usual $t$ and $F$ tests can be legitimately applied.

(ii) The Livestock Sector Output-Formal Credit Mo- del

Cointegration was tested on the data collected for this study using the Cointegrating Regression Durbin-Watson (CRDW) Test method. The computed DW $d(0.765)$ obtained from the cointegrating regression (10) is greater than the critical value of 0.386 at the $5 \%$ level, thus it was concluded that the regression residuals are stationary. However, the estimated DW $d$ value of 0.765 is lower than the critical DW $d_{L}$ value of 1.341, indicating an evidence of positive first order serial correlation (Appendix Table A1). The first-order difference transformation method was not used to remedy the detected autocorrelation problem because it is not appropriate for our case despite its other advantages. This decision is guided by Maddala (1992) rule of thumb on the appropriateness of using the first-order difference method: use the first difference transformation method whenever $d<R^{2}$. Our computed $d$ and $\mathrm{R}^{2}$ from equation (10) are 0.765 and 0.740 respectively i.e. $d>\mathrm{R}^{2}$. (See Appendix Table A2).

The Praise-Winsten transformation method, as expounded by Gujarati (2003) was used to transform the model, using $\rho$ estimated based on the Durbin-Watson $d$ statistic. This is done, based on the following assumptions: (a) that the error term in equation (10) follows the AR (1) scheme and (b) that if equation (3) holds true at time t, it also holds true at time $(\mathrm{t}-1)$, thus:

$$
\begin{gathered}
\operatorname{GDPL}_{\mathrm{t}-1}=\beta_{0}+\beta_{1} \mathrm{CrL}_{\mathrm{t}-1}+\mu_{\mathrm{t}-1} \\
\text { Multiplying equation }(12) \text { by } \rho \\
\rho \operatorname{GDPL}_{\mathrm{t}-1}=\rho \beta_{0}+\rho \beta_{1} \mathrm{CrL}_{\mathrm{t}-1}+\rho \mu_{\mathrm{t}-1}
\end{gathered}
$$

Subtracting equation (13) from equation (10)

$\left(\mathrm{GDPL}_{\mathrm{t}}-\rho \mathrm{GDPL}_{\mathrm{t}-1}\right)=\beta_{0}(1-\rho)+\beta_{1}\left(\mathrm{CrL}_{\mathrm{t}}+\rho \beta_{1} \mathrm{CrL}_{\mathrm{t}-1}\right)+\varepsilon_{\mathrm{t}}(14)$

Where $\varepsilon_{\mathrm{t}}=\left(\mu_{\mathrm{t}}-\rho \mu_{\mathrm{t}-1}\right)$

Equation (14) was then expressed as follows

$$
G D P L_{t}^{*}=\beta_{0}^{*}+\beta_{1}^{*} \operatorname{Cr} L_{t}^{*}+\varepsilon_{t}
$$

Where $\beta_{0}^{*}=\beta_{0}(1-\rho), G D P L_{t}^{*}=\left(G_{D P L}-\rho G D P L_{t-1}\right)$, $\operatorname{Cr} L_{t}^{*}=\left(\mathrm{CrL}_{\mathrm{t}}+\rho \beta_{1} \mathrm{CrL}_{\mathrm{t}-1}\right)$ and $\beta_{1}^{*}=\beta_{1}$. OLS was then applied to the transformed variables to obtain the usual optimum properties of the OLS coefficients asymptotically.

(iii) The Fishing Sector Output-Formal Credit Model

Cointegration was tested on the data collected for this study using the Cointegrating Regression Durbin-Watson 
(CRDW) Test method. The computed DW $d$ (0.533) obtained from the cointegrating regression (11) is greater than the critical value of 0.386 at the $5 \%$ level, thus it was concluded that the regression residuals are stationary. However, the estimated DW $d$ value of 0.533 is lower than the critical DW $d_{L}$ value of 1.341, indicating an evidence of positive first order serial correlation (Appendix Table A2). The first-order difference transformation method was used to remedy the detected autocorrelation problem because it is appropriate for our case in addition to its other advantages. This decision is guided by Maddala (1992) rule of thumb on the appropriateness of using the first-order difference method: use the first difference transformation method whenever $d<R^{2}$. Our computed $d$ and $\mathrm{R}^{2}$ from equation (11) are 0.533 and 0.670 respectively i.e. $d<\mathrm{R}^{2}$. (See Appendix Table A2).

Assuming $\rho=1$ and $\beta_{0}^{\prime}=\beta_{0}(1-\rho)=0$, the transformed model (11) becomes the following no-intercept model

Where

$$
\mathrm{GDP} F_{t}^{\prime}=\beta_{1}^{\prime} \mathrm{Cr} F_{t}^{\prime}+\mu_{\mathrm{t}}
$$

$$
\begin{array}{r}
\mathrm{GDPF}_{t}^{\prime}=\mathrm{GDPF}_{\mathrm{t}}-\mathrm{GDPF}_{\mathrm{t}-1} \\
\beta_{1}^{\prime} \mathrm{Cr} F_{t}^{\prime}=\beta_{1} \mathrm{CrF}_{\mathrm{t}}-\beta_{1} \mathrm{CrF}_{\mathrm{t}-1}
\end{array}
$$

The regression coefficient $\beta_{1}^{\prime}=\beta_{1}$ was directly estimated by OLS methods for regression through the origin.

\section{Results and Discussions}

\subsection{Relationship between Aggregate Output of the Crop Sector and Aggregate Amount of Formal Credit to the Crop Sector}

The aggregate crop sector output- credit model (9) is estimated using the time series data for the period 1981-2009 with SPSS 16.0. The F value of 76.493 computed for equation (9) is highly significant, when viewed in relation to the p-value of 0.000 . This implies that aggregate amount of formal credit to the crop sector significantly explain the variation in the aggregate output of the crop sector of the Nigerian agriculture. The $\mathrm{R}^{2}$ value obtained from the equation is 0.739 . This further indicates that the aggregate amount of formal credit to the crop sector explained about $74 \%$ of the variation in the aggregate output of the crop sector in Nigeria during the study period. This finding could be attributable to the fact that agricultural credit is supposed to increase farmers' access to resources and technologies necessary to boost agricultural production. The unexplained variation, $26 \%$, in the model is attributable to other factors not specified in the model due to difficulties in quantification and for computational ease.

The value of the estimated coefficient of formal credit to the crop sector, which measures the slope of the line, is 0.860 . This shows that as the quantity of formal credit increase by one naira (N1), the estimated increase in the output of the crop sector amounts to 86 kobo. (The Nigerian Naira is made up of 100 Kobos). The estimated value of the intercept, 540786.54 , indicates the mean level of output of the crop subsector when zero formal credit is made available to the subsector; it is the mean effect on the crop sector of all variables ommitted from the regression model. The value of the coefficient of correlation (r) of 0.860 shows that the 2 variables, output and credit, are highly positively correlated. The computed $t$ value of 8.746 calculated for $\beta_{1}$, the coefficient of formal credit to the crop sector, is found to be highly significant when viewed in relation to the computed p-value of 0.000 , hence the null hypothesis is rejected and it is thus concluded that there is a significant and positive relationship between the aggregate output of the crop sector and aggregate amount of formal credit to the crop sector in Nigeria.

Table 1. Results of Regression Analysis of aggregate crop sector outputcredit model (9)

\begin{tabular}{cccc}
\hline Independent Variables & Coefficients & t-values & p-values \\
\hline Constant term & 540786.535 & $2.056 \mathrm{a}$ & 0.050 \\
Formal Credit & $0.860^{*}$ & $8.746 \mathrm{a}$ & 0.000 \\
\hline
\end{tabular}

$\mathrm{R}^{2}=0.739 ;$ Adjusted $\mathrm{R}^{2}=0.729 ; \mathrm{R}=0.860 ; \mathrm{F}$ (model) $=76.493$; $\mathrm{p}$-value for $\mathrm{F}_{\text {(model) }}=0.000 ; \mathrm{DW} d=1.533$.

${ }^{\text {a }}$ Statistically significant statistics at $\alpha=5 \%,{ }^{*}$ Standardized

\subsection{Relationship between Aggregate Output of the Livestock Sector and Aggregate Amount of Formal Credit to the Livestock Sector}

The transformed aggregate livestock sector output- credit model (15) is estimated using the time series data for the period 1981-2009 with SPSS 16.0, in conjunction with MS Excel 2007. The $\mathrm{F}$ value of 65.686 computed for equation (15) is highly significant at the $5 \%$ level, when viewed in relation to the $p$-value of 0.000 . This implies that aggregate amount of guaranteed loan to the livestock sector significantly explain the variation in aggregate output of the livestock sector of the Nigerian agriculture. The R2 value obtained from the equation is 0.709 . This further indicates that the aggregate amount of formal credit to the livestock sector explained about $71 \%$ of the variation in the aggregate output of the livestock sector in Nigeria during the study period. This finding could be attributable to the fact that agricultural credit is supposed to increase farmers' access to resources and technologies necessary to boost agricultural production. The unexplained variation, $29 \%$, in the model is attributable to other factors not specified in the model due to difficulties in quantification and for computational ease.

The value of the estimated coefficient of formal credit to the livestock sector, which measures the slope of the line, is 0.842 . This shows that as the quantity of formal credit increase by one naira $(\mathrm{N} 1)$, the estimated increase in the output of the livestock sector amounts to 84 kobo. The estimated value of the intercept, 24912.31, indicates the mean level of output of the crop subsector when formal credit made available to the subsector is zero; it is the mean effect on the crop sector of all variables ommitted from the regression model. The value of the coefficient of correlation (r) of 0.842 
shows that the 2 variables, output and credit, are highly positively correlated.

The computed t value of 8.105 calculated for $\beta_{1}$, the coefficient of guaranteed formal credit to the livestock sector, is found to be highly significant when viewed in relation to the computed p-value of 0.000 , hence the null hypothesis is rejected and it is thus concluded that there is a significant relationship between aggregate output of the livestock sector and aggregate amount of formal credit to the livestock sector in Nigeria.

Table 2. Results of Regression Analysis of the transformed aggregate livestock sector output- credit model (15)

\begin{tabular}{|c|c|c|c|}
\hline Independent Variables & Coefficients & $\mathrm{t}$-values & $\mathrm{p}$-values \\
\hline Constant term & 24912.31 & & \\
\hline Formal Credit & $0.842^{*}$ & $8.105^{\mathrm{a}}$ & 0.000 \\
\hline
\end{tabular}

\subsection{Relationship between Aggregate Output of the Fishing Sector and Aggregate Amount of Formal Credit to the Fishing Sector}

The transformed aggregate fishing sector output- credit model (16) is estimated using the time series data for the period 1981-2009 with SPSS 16.0. The F value of 19.132 computed for equation (16) is highly significant at the $5 \%$ level, when viewed in relation to the p-value of 0.000 . This implies that aggregate amount of formal credit to the fishing sector significantly explain the variation in aggregate output of the fishing sector of the Nigerian agriculture.

The value of the estimated coefficient of formal credit to the fishing sector, which measures the slope of the line, is 0.651 . This shows that as the quantity of formal credit increase by one naira (N1), the estimated increase in the output of the fishing sector amounts to 65 kobo. The computed $t$ value of 4.374 calculated for $\beta_{1}$, the coefficient of guaranteed formal credit to the fishing sector, is found to be highly significant when viewed in relation to the computed p-value of 0.000 , hence the null hypothesis is rejected and it is thus concluded that there is a significant relationship between aggregate output of the fishing sector and aggregate amount of loans guaranteed to the fishing sector in Nigeria.

Table 3. Results of Regression Analysis of first-difference aggregate fishing sector output- credit model (16).

\begin{tabular}{cccc}
\hline Independent Variables & Coefficients & t-values & p-values \\
\hline Formal Credit & $0.651^{*}$ & $4.374^{\text {a }}$ & 0.000 \\
\hline $\mathrm{F}_{\text {(model) }}=76.493 ; \mathrm{p}$-value for $\mathrm{F}_{\text {(model) }}=0.000 ; \mathrm{DW} d=1.533$. \\
${ }^{\mathrm{a}}$ Statistically significant statistics at $\alpha=5 \%,{ }^{*}$ Standardized
\end{tabular}

The findings of this study indicates that formal credit is positively and significantly related to the productivity of the crop, livestock and fishing subsectors of the Nigerian agricultural sector. These findings are in agreement with several other studies elsewhere (Sial et al, 2011; Bashir et al, 2010; Iqbal et al, 2003, Olagunju, 2007 and CBN, 2007).

\section{Conclusions}

The paper set out to investigate the relationship between agricultural production and formal credit supply in Nigeria. The methodology employed in the study involved the estimation of three simple regression models relating agricultural output with formal credit while holding other explanatory variables constant. Findings of the paper indicates that (i) there is a positive and significant relationship between aggregate output of the crop sector and aggregate amount of formal credit to the crop sector. (ii) There is a significant and positive relationship between aggregate output of the livestock sector and aggregate amount of formal credit to the livestock sector. (iii) There is a significant and positive relationship between aggregate output of the fishing sector and aggregate amount of formal credit to the fishing sector. Thus, it is concluded that formal credit is positively and significantly related to the productivity of the crop, livestock and fishing sectors of Nigerian agriculture. Based on the findings it is recommended that government should continue to encourage the expansion of formal credit sources to reach as much farmers as possible.

\section{Appendix}

Table A1. Results of Regression Analysis of aggregate Livestock sector GDP- credit model (10) Level model

\begin{tabular}{|c|c|c|c|}
\hline Independent Variables & Coefficients & t-values & $\mathrm{p}$-values \\
\hline Constant term & 64037.797 & $3.627^{\mathrm{a}}$ & 0.001 \\
\hline Formal Credit & $0.860^{*}$ & $8.763^{\mathrm{a}}$ & 0.000 \\
\hline
\end{tabular}

$\mathrm{R}^{2}=0.740 ;$ Adjusted $\mathrm{R}^{2}=0.730 ; \mathrm{R}=0.860 ; \mathrm{F}_{\text {(model) }}=76.789 ; \mathrm{p}$-value for $\mathrm{F}_{(\text {model })}=0.000$; $\mathrm{DW} d=0.765$.

${ }^{\text {a }}$ Statistically significant statistics at $\alpha=5 \%$

"Standardized

Table A2. Results of Regression Analysis of aggregate Fishing sector GDP- credit model (11) Level model

\begin{tabular}{|c|c|c|c|}
\hline Independent Variables & Coefficients & t-values & $\mathrm{p}$-values \\
\hline Constant term & 34290.289 & $3.317^{\mathrm{a}}$ & 0.003 \\
\hline Formal Credit & $0.819^{*}$ & $7.269^{\mathrm{a}}$ & 0.000 \\
\hline
\end{tabular}

$\mathrm{R}^{2}=0.670$; Adjusted $\mathrm{R}^{2}=0.658 ; \mathrm{R}=0.819 ; \mathrm{F}_{\text {(model) }}=52.834 ; \mathrm{p}$-value for $\mathrm{F}_{(\text {model })}=0.000 ; \mathrm{DW} d=0.533$.

${ }^{a}$ Statistically significant statistics at $\alpha=5 \%$

*Standardized 
Table A3. Time Series Data on the contributions of the crop, livestock and fishing sector to national GDP at current prices alongside corresponding guaranteed loan volume by purpose in Nigeria (1981-2009)

\begin{tabular}{|c|c|c|c|c|c|c|}
\hline Year & $\begin{array}{c}{ }^{\text {a Crop Sector }} \\
\text { GDP (N Millions) }\end{array}$ & $\begin{array}{l}{ }^{\text {a}} \text { Livestock Sector } \\
\text { GDP (N Millions) }\end{array}$ & $\begin{array}{c}{ }^{\mathrm{a}} \text { Fishing Sector } \\
\text { GDP } \\
\text { (N Millions) }\end{array}$ & $\begin{array}{l}{ }^{\mathrm{b}} \text { Quantity of Crop } \\
\text { Sector Guaranteed } \\
\text { Loans (N Millions) }\end{array}$ & $\begin{array}{c}{ }^{\text {b}} \text { Quantity of Livestock } \\
\text { Sector Guaranteed } \\
\text { Loans (N Millions) }\end{array}$ & $\begin{array}{l}{ }^{\text {b }} \text { Quantity of Fishing } \\
\text { Sector Guaranteed } \\
\text { Loans (N Millions) }\end{array}$ \\
\hline 1981 & 10088 & 1706.8 & 723.3 & 9.606 & 25.148 & - \\
\hline 1982 & 11274 & 2678.6 & 885.1 & 6.404 & 21.836 & 0.0396 \\
\hline 1983 & 12870 & 3510.4 & 1297.7 & 12.111 & 21.79 & 1.575 \\
\hline 1984 & 16920 & 4474.7 & 1140.8 & 6.118 & 11.817 & 0.826 \\
\hline 1985 & 19729 & 4841.6 & 710.3 & 18.549 & 14.159 & 0.7181 \\
\hline 1986 & 20442 & 4994.9 & 1010.8 & 41.064 & 25.804 & 1.645 \\
\hline 1987 & 31214 & 5660.3 & 873.7 & 70.697 & 29.388 & 4.526 \\
\hline 1988 & 48679 & 6009.2 & 1532.4 & 97.836 & 18.48 & 4.537 \\
\hline 1989 & 56577.4 & 7970.2 & 3173.3 & 115.552 & 7.875 & 4.539 \\
\hline 1990 & 68416.7 & 9562 & 4216.8 & 88.856 & 4.967 & 3.901 \\
\hline 1991 & 80002 & 10528.8 & 4701.3 & 71.405 & 4.447 & 1.698 \\
\hline 1992 & 120720.1 & 15565.6 & 6199.5 & 82.684 & 6.056 & 1.039 \\
\hline 1993 & 196133.8 & 24723.8 & 7341.7 & 72.637 & 5.506 & 0.428 \\
\hline 1994 & 296966.8 & 36707.5 & 10090.8 & 90.166 & 10.528 & 2.438 \\
\hline 1995 & 527474.4 & 65704.6 & 19067.3 & 134.567 & 18.049 & 1.512 \\
\hline 1996 & 713786.1 & 88150.2 & 30022.9 & 187.012 & 28.217 & 2.145 \\
\hline 1997 & 807759.8 & 98033.8 & 36255.7 & 201.248 & 23.405 & 3.555 \\
\hline 1998 & 892052.7 & 107013.7 & 43970 & 182.962 & 22.587 & 3.456 \\
\hline 1999 & 948183 & 111110.1 & 50715.8 & 208.978 & 11.952 & 6.18 \\
\hline 2000 & 1000069.5 & 116393.4 & 54010.3 & 308.605 & 27.307 & 0.899 \\
\hline 2001 & 1337766.6 & 154495.5 & 75170.9 & 622.695 & 60.416 & 15.742 \\
\hline 2002 & 3050243.5 & 183202.2 & 90431.2 & 938.949 & 64.45 & 12.069 \\
\hline 2003 & 3275429.2 & 202263.1 & 106466.1 & 1026.156 & 100.486 & 13.05 \\
\hline 2004 & 3478096.4 & 243887.5 & 130116.5 & 1825.853 & 190.304 & 18.24 \\
\hline 2005 & 4228282.2 & 313252.3 & 169878 & 8321.932 & 844.883 & 262.195 \\
\hline 2006 & 5291619.1 & 378702.6 & 196454.2 & 3770.549 & 368.151 & 114.4 \\
\hline 2007 & 6024381 & 434151.7 & 215523 & 3913.774 & 353.487 & 140.69 \\
\hline 2008 & 7114794 & 512943.5 & 254637.2 & 4965.965 & 1108.484 & 368.63 \\
\hline 2009 & 8207652.7 & 584940.7 & 290933.9 & 5794.654 & 1725.801 & 708.621 \\
\hline
\end{tabular}

\section{REFERENCES}

[1] Ammani, A. A., J. F. Alamu and T. M. Kudi. 2010. Input Supply and the Development of Commercial Agriculture in Nigeria: Constraints to Fertilizer Use in Maize Production in Kaduna State. In Nmadu, J. N., M. A. Ojo, U. S. Mohammed, K. M. Baba, F. D. Ibrahim and E. S. Yisa (Eds). Commercial Agriculture, Banking Reform and Economic Downturn: Setting a New Agenda for Agricultural Development in Nigeria. Proceedings of the $11^{\text {th }}$ Annual National Conference of the Nigerian Association of Agricultural Economists held at the School of Agriculture and Agricultural Technology, Federal University of Technology, Minna, Nigeria from $30^{\text {th }}$ November $-3^{\text {rd }}$ December 2010. Pp 60-65

[2] Bashir, M. K., Mehmood, Y. and Hassan, S. 2010. Impact of Agricultural Credit on Productivity of Wheat Crop: Evidence from Lahore, Punjab, Pakistan. Pak. J. Agri. Sci., 47(4), 405-409

[3] Carter, M. R. 1989. The Impact of Credit on Peasant Productivity and Differentiation in Nicaragua. Journal of Development Economics 31, 13-36

[4] CBN 1990. Agricultural Credit Guarantee Scheme Fund
Guidelines For The Agricultural Credit Guarantee Scheme. Lagos: CBN

[5] Central Bank of Nigeria. 2007. Agricultural Credit Guarantee Scheme Fund of Nigeria (ACGSF): An impact assessment. Abuja: CBN

[6] CBN 2011. Gross Domestic Product 2009 at Current Prices. Retrieved from www.cenbank.org/documents on the $7^{\text {th }}$ of May 2011 at 23:54

[7] CBN 2011. ACGSF Loans Volume by Purpose 2009. Retrieved from www.cenbank.org/documents on the $7^{\text {th }}$ of May 2011 at $23: 58$

[8] Qureshi, S., Nabi, I., and Faaruquee, R. 1996. Rural Finance for Growth and Poverty Alleviation. World Bank Policy Research Working Paper No 1593. Washington DC: World Bank

[9] Enders, W. 1995. Applied Econometric Time Series. New York: John Wiley and Sons

[10] Eswaram, M. and Kotwal, A. 1990. Implications of Credit Constraints for Risk Behavior in Less-developed Countries. Oxford Economic Papers 42. Oxford: Oxford University Press

[11] Feder, G., Just, R. E., and Zilberman, D. 1985. Adoption of Agricultural Innovations in Developing Countries. Economic 
Development and Cultural Change 22 2: 255-296

[12] Food and Agriculture Organization, 2006. Rural credits guarantee schemes: a financial instrument for agriculture and rural development. Workshop on same issue, summary of report, Budapest

[13] Gujarati, D. N. 2003. Basic Econometrics. $4^{\text {th }}$ edn. New Delhi: Tata McGraw-Hill

[14] Hollinger, H., 2004. Financing agricultural term investment. Agricultural finance revisited series, 7. Rome: FAO

[15] Iqbal, M., Ahmad, M. and Abbas, K. 2003. The Impact of Institutional Credit on Agricultural Production in Pakistan. The Pakistan Development Review 42:469-485

[16] Maddala, G. S. 1992. Introduction to Econometrics, Second Edn. New York: Macmillan

[17] Okon, X. A., and Nkang N. M. 2009. An Assessment of Nigeria's Agricultural Credit Guarantee Scheme Fund: Evidence From Time-Series Analysis. Global Journal of Agricultural Sciences 8 2:133 -145

[18] Olagunju, F.I. 2007. Impact of Credit Use on Resource Productivity of Sweet Potatoes Farmers in Osun State, Nigeria. Journal of Social Sciences 14(2):175-178
[19] [19] Patterson, K. 2000. An Introduction to Applied Econometrics: A Time Series Approach. New York: St. Martin's Press

[20] Reichmuth, M., 1997. Credit guarantee schemes for small enterprises: an assessment. Warsaw, Workshop on Polish Agricultural and Rural Credit Guarantees, presented paper

[21] Seddighi, H. R., K. A. Lawler and A. V. Katos. 2000. Econometrics: A Practical Approach. New York: Routledge

[22] Sial, M. H, Awan, M. S. and Waqas, M. 2011. Role of Institutional Credit on Agricultural Production: A Time Series Analysis of Pakistan. International Journal of Economics and Finance 3 2: 126-132

[23] World Bank. 1994. The Nigerian Rural Financial System: Assessment and Recommendations. AF4AE Department of the World Bank. Washington DC: World Bank

[24] World Bank .2000. Financing Nigeria's Rural Micro and Small-Scale Enterprises. Main Report. Washington DC: World Bank

[25] Zeller, M. 1999. The Role of Rural Financial Services for Alleviation of Food insecurity and Poverty. Agriculture and Rural Development. 6 2: 28-32 